\title{
Gains of Steers and Calves Grazing Crested Wheatgrass
}

R.H. HART, E.F. BALLA, AND J.W. WAGGONER, JR.

\begin{abstract}
Efficient utilization of pasture requires proper class of livestock, stocking rate, and season of use. Crested wheatgrass was grazed with steers in spring for 3 years at two stocking rates and with calves in fall for 2 years at $\mathbf{2}$ stocking rates to evaluate alternate uses. Differences in forage production and lengths of grazing season over years produced grazing pressures of 47-79 steer days or 53-73 calf days per metric tonne of forage produced. Steer gains of $0.85-1.20 \mathrm{~kg} /$ day were unaffected by grazing pressure, but lighter steers gained faster. Implantation of $36 \mathrm{mg}$ of Ralgro per steer increased daily gains by $13 \%$. Calf gains were $0.15-0.24$ $\mathrm{kg} / \mathrm{day}$, and decreased with increasing grazing pressure according to the function $A D G=0.45-0.0041$ (calf days/tonne forage); $r^{2}=0.95$. Such grazing pressure-gain response functions facilitate comparisons between seasons of use and class of livestock, as well as those between stocking rates, and help range managers make management decisions. Ma ximum steer gains in spring per hectare and tonne of forage were over 3 and 6 times, respectively, the gains of calves in fall.
\end{abstract}

Crested wheatgrass (Agropyron desertorum [Fisch.] Schult.) is widely used in the Northern Great Plains as complementary pasture with native range. Generally forage production is higher than that of native range and quality is higher than that of range forage in spring (Hart et al. 1983a). However, Bedell (1973), Rauzi (1975), and Hart et al. (1983a) reported that forage quality of crested wheatgrass decreases rapidly as it matures. In comparisons with native range, crested wheatgrass has produced higher average daily gains, greater carrying capacity, and better reproductive performance of cattle in a number of studies (Hart al. 1983b, Frischknecht et al. 1953, Hedrick et al. 1969, Lodge 1963 and 1970 , Smoliak 1968, Smoliak and Slen 1974, and Springfield and Reid 1967).

Most efficient use of any pasture is achicved only at the optimum stocking rate or grazing pressure (Hart 1972 and 1978) and season of use. We evaluated crested wheatgrass as spring and summer pasture for yearling steers at grazing pressures of 47-79 steer days/t of herbage produced at the High Plains Grasslands Research Station near Cheyenne, Wyo. Later at the same location we evaluated season-long accumulation of crested wheatgrass at grazing pressures of 53-73 calf days/ $t$ as fall pasture for recently weaned calves.

\section{Materials and Methods}

Yearling Hereford steers grazed two 13-ha crested wheatgrass pastures in spring and early summer of 1976 through 1978 . These pastures were located on sandy to gravelly loam overlaying gravel and cobbles, and supported a rather open stand of crested wheatgrass. Forage production was estimated by clipping two $0.124 \mathrm{~m}^{2}$

\footnotetext{
Authors are respectively, agronomist, USDA, Agricultural Rescarch Service, Cheyenne, Wyo.; range scientist, Range Management Administration, Khartoum, Sudan; and animal nutritionist, Division of Animal Science, University of Wyoming, Laramie. This research was carried out at the High Plains Grasslands Research Station, 8408 Hildreth Road, Cheyenne, Wyo. 82009 . under cooperative agreements of USDA, ARS, with the University of Wyoming and Colorado State University. Manuscript received June 9, 1982.
}

quadrats inside each of 5 cages per pasture at the end of each grazing season, to a $1-\mathrm{cm}$ stubble height. Crested wheatgrass was in full bloom when clipped in 1976 and 1977, and at the soft dough stage in 1978. The open stand and poor water-holding capacity of the soil resulted in low spring forage production, which averaged $1060 \mathrm{~kg} / \mathrm{ha}$ over the 3 years of this study. Stocking rates were 1.08-1.54 steers/ha, and grazing seasons were 42-56 days. In 1977 and 1978 , half the steers on each pasture received a $36 \mathrm{mg}$ Ralgro' implant just before grazing began.

Hereford calves grazed 2 crested wheatgrass pastures of 7.6 and 10.3 ha starting 1 week after weaning in the fall of 1979 and 1980 . These pastures were on a deep sandy loam. Because of higher waterholding capacity of the soil, better stand, and the fact that forage was accumulated without grazing throughout the grazing season, forage production was higher on these pastures than on the steer pastures. Production, measured by clipping to a $1-\mathrm{cm}$ stubble height in 5 cages per pasture as in the steer study, averaged 2,490 $\mathrm{kg} / \mathrm{ha}$ for the 2 years. Stocking rates were 2.33-3.30 calves/ ha, and the grazing season was 49 days in 1979 and 63 days in 1980.

In both experiments, cattle were weighed every 2 weeks, after being held overnight without feed or water. Initial cattle weights, stocking rates, forage production, grazing pressures, and gains by year and treatment are summarized in Table 1. Data were analyzed by regression and analysis of variance.

\section{Results and Discussion}

In each of 3 years, analysis of variance showed no significant difference between stocking rates in average daily gains of steers (Table 1), indicating that forage availability did not limit gains. As grazing pressures up to 79 steer days per metric tonne of forage did not reduce gains, we concluded that grazing pressures must exceed this level before average daily gains will decrease. Gains in 1977 were much higher than in 1976 or 1978 because the steers were much lighter and thinner when they went on pasture in 1977. Such animals require less feed and energy per unit gain than do heavier, fatter animals because less energy is needed for maintenance (NAS-NRC 1976, Morley 1978) and a greater proportion of the gain is lean, which requires less energy to deposit than does fat (Corbett 1978). Regression analysis indicated that initial weight accounted for $90 \%$ of the variation in average daily gain over grazing pressures and years.

Daily gains under light stocking in 1978 and 2-year mean daily gains under both stocking rates were significantly increased by Ralgro implants (Table 2). This increase averaged $13 \%$ over both stocking rates and years.

Gain per tonne of forage produced reached a maximum of $82 \mathrm{~kg}$ on the high stocking rate in 1977. According to NAS-NRC feeding standards (1976) these steers, gaining $1.17 \mathrm{~kg} /$ day, would have needed about $4.9 \mathrm{~kg}$ of TDN per day. Hart et al. (1983a) found that in vitro dry matter digestibility (IVDMD) of crested wheatgrass averaged about $64 \%$ from mid-May until end of June. Given a stocking pressure of 70 steer days per tonne of forage, $60 \%$ utiliza-

Mention of a trademark or proprietary product does not constitute its approval by USDA to the exclusion of similar products. 
Table 1. Performance of yearling steers and weaner calves grazing crested wheatgrass pasture in spring and fall, respectively.

\begin{tabular}{|c|c|c|c|c|c|c|c|c|c|}
\hline \multirow[b]{2}{*}{ Grazed by } & \multirow[b]{2}{*}{ Grazing season } & \multirow{2}{*}{$\begin{array}{l}\text { Initial } \\
\text { weight } \\
(\mathrm{kg})\end{array}$} & \multirow{2}{*}{$\begin{array}{c}\text { Stocking } \\
\text { rate } \\
\text { (head/ha) }\end{array}$} & \multirow{2}{*}{$\begin{array}{c}\text { Forage } \\
\text { production } \\
(\mathrm{kg} / \mathrm{ha})\end{array}$} & \multicolumn{2}{|c|}{ Animal days } & \multicolumn{3}{|c|}{ Gain $(\mathrm{kg})$} \\
\hline & & & & & /ha & $/ \mathrm{t}$ & /day & /ha & $/ \mathrm{t}$ \\
\hline $\begin{array}{l}\text { Steers } \\
\text { (spring) }\end{array}$ & $\begin{array}{l}17 \text { May-2 July } 1976 \\
\text { (46 days) } \\
24 \text { May-5 July } 1977 \\
\text { (42 days) } \\
30 \text { May-25 July } 1978 \\
\text { (56 days) }\end{array}$ & $\begin{array}{l}298 \\
235 \\
271\end{array}$ & $\begin{array}{l}1.16 \\
1.54 \\
1.08 \\
1.62 \\
1.16 \\
1.54\end{array}$ & $\begin{array}{c}1130 \pm 110^{1} \\
970 \pm 90 \\
1090 \pm 120\end{array}$ & $\begin{array}{l}53.3 \\
71.0 \\
45.4 \\
68.1 \\
64.9 \\
86.5\end{array}$ & $\begin{array}{l}47.2 \\
62.9 \\
46.8 \\
70.2 \\
59.5 \\
79.4\end{array}$ & $\begin{array}{l}.71 \pm .041 \\
.85 \pm .05 \\
1.20 \pm .06 \\
1.17 \pm .04 \\
.92 \pm .05 \\
.85 \pm .04\end{array}$ & $\begin{array}{r}37.7 \\
60.5 \\
54.5 \\
114.9 \\
59.5 \\
73.6\end{array}$ & $\begin{array}{l}33.4 \\
53.6 \\
56.2 \\
82.1 \\
54.7 \\
67.5\end{array}$ \\
\hline $\begin{array}{l}\text { Calves } \\
\text { (fall) }\end{array}$ & $\begin{array}{l}2 \text { Oct. }-20 \text { Nov. } 1979 \\
\text { (49 days) } \\
17 \text { Sept. }-19 \text { Nov. } 1980 \\
\text { (63 days) }\end{array}$ & $\begin{array}{l}186 \\
200\end{array}$ & $\begin{array}{l}2.43 \\
3.30 \\
2.33 \\
2.91\end{array}$ & $\begin{array}{l}2220 \pm 500 \\
2760 \pm 620\end{array}$ & $\begin{array}{l}119.2 \\
161.9 \\
147.1 \\
183.1\end{array}$ & $\begin{array}{l}53.7 \\
72.9 \\
53.3 \\
66.4\end{array}$ & $\begin{array}{l}.22 \pm .03 \\
.15 \pm .02 \\
.24 \pm .02 \\
.18 \pm .03\end{array}$ & $\begin{array}{l}26.3 \\
24.5 \\
35.7 \\
33.3\end{array}$ & $\begin{array}{l}11.8 \\
11.0 \\
13.0 \\
12.1\end{array}$ \\
\hline
\end{tabular}

${ }^{1}$ Mean \pm standard error of mean.

tion, and 64\% IVDMD, one calculates an estimated consumption plus waste of $8.6 \mathrm{~kg}$ of dry matter and $5.5 \mathrm{~kg}$ of IVDMD steer per day. Thus even this large gain was in line with predicted values.

Calf daily gains on crested wheatgrass in the fall were much lower than steer gains in spring. Gains on crested wheatgrass were also less than gains on range just before weaning. Calf average daily gains were 0.84 and $0.72 \mathrm{~kg}$ during the last 4 weeks on range in 1979 and 1980 , respectively. These differences in gain reflect (1) the low quality of mature forage accumulated since spring, (2) the fact that calves used only a small part of this forage, and (3) the slowing in rate of gain following weaning. Miller (1958) reported $5.9 \%$ crude protein, $37 \%$ crude fiber, and $17 \%$ lignin in mature crested wheatgrass, and $3.3 \%$ crude protein and $41 \%$ crude fiber in "very mature" crested wheatgrass. Cook and Harris (1952) observed that sheep ate only the leaves of mature crested wheatgrass, and calves appeared to be as selective, eating mostly the leaves on mature stems remaining from spring growth and the small amount of fall regrowth. Thus total herbage production grcatly overestimated grazeable forage.

Average daily gains of calves declined significantly as grazing pressure increased. This decline was described by the equation $\mathrm{ADG}=0.45-0.0041$ (calf days/tonne forage). This equation accounted for $95 \%$ of the variation in daily gains, and was significant at the $5 \%$ level, but was based on only 4 points. Also keep in mind that it applies only to calves grazing low-quality accumulated growth of crested wheatgrass in the fall, and should not be extrapolated to other types and qualities of forage or classes of cattle.

Objections may be raised to comparisons between spring grazing with steers and fall grazing with calves. However, a range manager must make comparisons of this kind regularly when deciding on season of use, class of stock, and stocking rate for a particular pasture. Grazing pressure-gain response curves provide a rational basis for such decisions.

Maximum gain of steers per tonne of forage produced was over 6 times the maximum gain of calves. This demonstrates that grazing of crested wheatgrass with steers in the spring, when it is most

Table 2. Gains of steers grazing crested wheatgrass pasture in spring, with without Ralgro implants.

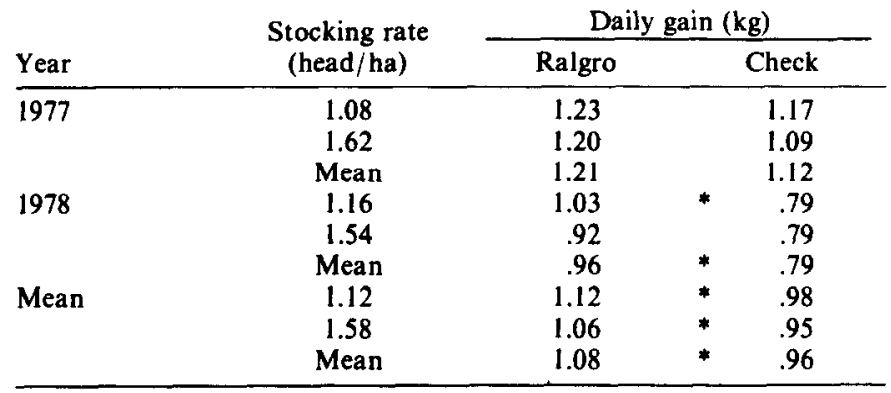

*Gains under Ralgro and check signifiantly different, $5 \%$ level. palatable and nutritious, converts grass to gain much more efficiently than fall grazing of accumulated grass with calves. However, if the calf pastures had been grazed in the spring and then calves allowed to graze fall regrowth, their efficiency might have been higher.

\section{Literature Cited}

Bedell, T.E. 1973. Clipping effects on growth form, yield, and nutritive quality of crested wheatgrass in eastern Wyoming. Wyoming Agr. Exp. Sta. Res. J. 76.

Cook, C.W., and L.E. Harris. 1952. The nutritive value of cheatgrass and crested wheatgrass on spring ranges in Utah. J. Range Manage. 5:331337.

Corbett, J.L. 1978. Measuring animal performance. In: Measurement of Grassland Vegetation and Animal Production. L. ' $t$ Mannetje (ed.) Bull. 52, Commonwealth Bur. Past. Field Crops, p. 163-231. Commonwealth Agr. Bur., Hurley, Berks., England.

Frischknecht, N.C., L.E. Harris, and H.K. Woodward. 1953. Cattle gains and vegetal changes as influenced by grazing treatments on crested wheatgrass. J. Range Manage. 6:151-158.

Hart, R.H. 1972. Forage yield, stocking rate, and beef gains on pasture. Herbage Abstr. 42:345-353.

Hart, R.H. 1978. Stocking rate theory and its application to grazing on rangelands. Proc. 1st Int. Rangeland Cong., p. 547-550.

Hart, R.H., O.M. Abdalla, D.H. Clark, M.B. Marshall, M.H. Hamid, J.A. Hager, and J.W. Waggoner Jr. 1983a. Quality of forage and cattle diets on the Wyoming High Plains. J. Range Manage. 36:46-51.

Hart, R.H., J.W. Waggoner Jr., D.H. Clark, C.C. Kaltenbach, J.A. Hager, and M.B. Marshall. 1983b. Beef cattle performance on crested wheatgrass plus native range vs. native range alone. J. Range Manage. 36:3840.

Hedrick, D.W., W.M. Moser, A.L. Steninger, and R.A. Long. 1969. Animal performance on crested wheatgrass during May and June, Fort Rock, Oregon. J. Range Manage. 22:277-280.

Lodge, R.W. 1963. Complementary grazing systems for sandhills of the Northern Great Plains. J. Range Manage. 16:240-244.

Lodge, R.W. 1970. Complementary grazing systems for the Northern Great Plains. J. Range Manage. 23:268-271.

Miller, D.F. 1958. Composition of cereal grains and forages. Pub. 585, NAS-NRC, Washington, D.C.

Morley, F.H.W. 1978. Animal production studies on grassland. In: Measurement of Grassland Vegetation and Animal Production. L. 't Mannetje (ed.) Bull. 52, Commonwealth Bur. Past. Field Crops, p. 103-162. Commonwealth Agr. Bur., Hurley, Berks., England.

National Academy of Sciences and National Research Council. 1976. Nutrient requirements of beef cattle, 5th rev. ed. Natur. Acad. Sci., Washington.

Rauxi, 1975. Seasonal yield and chemical composition of crested wheatgrass in southeastern Wyoming. J. Range Manage. 28:219-221.

Smoliak, S. 1968. Grazing studies on native range, crested wheatgrass, and Russian wildrye pastures. J. Range Manage. 21:47-50.

Smoliak, S., and S.B.Slen. 1974. Beef production on native range, crested wheatgrass, and Russian wildrye pastures. J. Range Manage. 27:433436.

Springfield, H.W., and E.H. Reid. 1967. Crested wheatgrass for spring grazing in northern New Mexico. J. Range Manage. 20:406-408. 